\title{
光音響顕微鏡ならびに映像法とその生物および医学への応用
}

\author{
星宮務 \\ 東北学院大学 工学部物理情報工学科 大学院工学研究科応用物理学専攻 ( $9985-8537$ 宮城県多賀城市中央1丁目13-1)
}

\section{Applications of Photoacoustic Microscopy and Imaging to Biological and Medical Science and Technology}

\author{
Tsutomu HOSHIMIYA
}

Department of Applied Physics and Informatics, Faculty of Engineering, Course of Applied Physics, Graduate school of Engineering, Tohoku Gakuin University,13-1, Chuo 1, Tagajyo, Miyagi 985-8537

(Received May 6, 2004)

\begin{abstract}
In this article, the basic principle of photoacoustic microscope (PAM) and imaging was introduced paying the special attention to its detection schemes. The experimental apparatus and applications of PAM were reviewed. Depth profiling using PAM in the nondestructive inspection of semiconductor device was discussed. The principle of spectroscopic analysis method by integration over PAM image measured with respect chemical reagent concentraion or pollen number was also discussed. Furthermore, photoacoustic imaging technique including photoacoustic tomography applied to biological imaging was reviewed.
\end{abstract}

Key Words: Photoacoustic microscopy, Imaging, Dry chemical, Pollen, Tomography

\section{1. 序 論}

A. G. Bellによる光音響効果の発見と1970年代以降の レーザーの発明によるその再発見以来, 光音響法 ${ }^{1-8)}$ の最 大の応用の一つとして考えられるものに光音響顕微鏡9-11) がある．光音響顕微鏡の最大の特徵は試料の表面および 内部の光学的性質, 熱的性質, 弾性的性質のすべてに関 わる事ができる点であろう。また光によって発生した熱 が, 光が内部まで到達できない固体試料内部にまで拡 散, 浸透し得る事を利用しているため, 構造物や部品内 部の非破壞検査などの不可視試料への応用も考えられて いる.

この解説論文では, 本特集で取り上げられている光音 響顕微鏡，ならびに空間分解能はもう少し大きいがほぼ 同一の原理に基づく光音響映像法を取り上げて，これら の理論的基礎などについての総合的な記述をした後に, それらの生物・医学的な応用にも言及して紹介して行き たい.

\section{2. 音響顕微鏡の理論}

光音響効果に基づいて試料の可視化を行うには，ほと んどの場合，固体試料を前提としている.

Fig. 1に光音響顕微鏡の概念図を示す．周期的に変調され たレーザー光をレンズ等の光学系で固体試料の表面の一

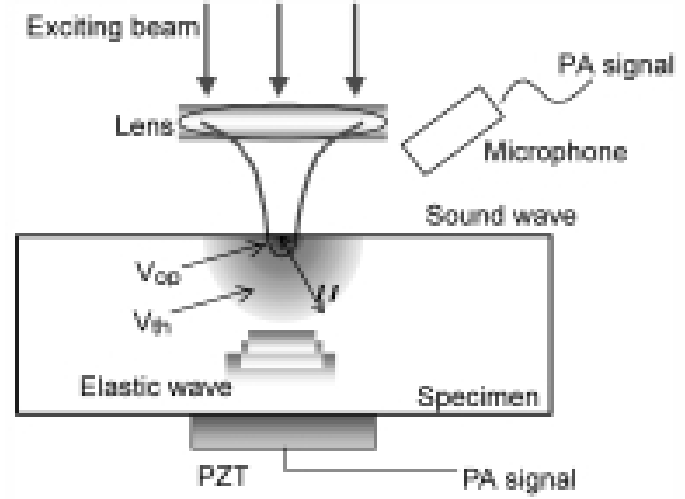

Fig. 1 The principle of a photoacoustic microscope (PAM).

部に収束させると, 吸収した光エネルギーの一部は試料 内部で熱エネルギーに変換され, 試料表面に周期的な温 度上昇を生じる。密閉容器に試料を封入し，その周囲を 気体が取り囲んでいる場合には，試料表面に接している 気体の一部(境界層)が暖められ断熱的に膨張することによ り周囲気体に疎密波が発生する。同時に固体試料内部に 熱弾性波が発生する．発生する信号を光照射する試料表 面の1点ごとにマイクロフォンや圧電素子等のセンサーで 検出して映像化する装置を光音響顥微鏡 (photoacoustic microscope: PAM) と呼び, この手法を光音響映像法 (photoacoustic imaging) と呼ぶ.

映像化に応用するための変調法としては，正弦波変調 
法の他に, パルス励起法 ${ }^{12)}$, ランダム変調した励起光に 対する応答を励起光と相互相関を取ってインパルス応答 を求める相関手法 ${ }^{13)}$, その他各種の変調法がこれまでに 行われている。ここでは簡単のために正弦波変調法に基 づいて議論を展開する。この場合には周期的な温度場が 生じ, 一種の波動として取り扱えるので,「熱波 (thermal wave)」と呼ばれる。

この様な状況下で成り立つ光音響信号強度の解析には, ガス・マイクロフォン法を用いる場合にはRosencwaigGersho理論 ${ }^{14)}$ が用いられ, 試料に直接圧電素子を接着して 用いる場合にはJackson-Amer理論15) が用いられる。理論の 詳細は原論文に譲り，ここでは結論のみを述べたい。

\section{1 ガス・マイクロフォン法}

固体試料における光吸収により熱が発生し, その熱源 から熱が拡散するのが光音響法の基本原理で, 熱源を含 む熱拡散方程式からスタートする。 Thomasらの理論16)に よれば，変調周波数正で正弦波変調した場合の光音響信号

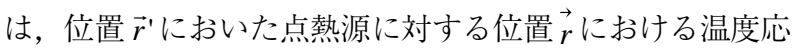
答を与えるGreen関数

$$
\begin{aligned}
& G\left(\vec{r} ; \overrightarrow{r^{\prime}}\right) \\
& \Delta^{2} G\left(\vec{r} ; \overrightarrow{r^{\prime}}\right)-\sigma^{2} G\left(\vec{r} ; \overrightarrow{r^{\prime}}\right)=-\frac{\alpha \eta}{\kappa} \cdot I_{0} \cdot \delta\left(\vec{r}-\overrightarrow{r^{\prime}}\right)
\end{aligned}
$$

により求められる。ここにのは複素数で

$$
\sigma=(1-i) \sqrt{\frac{\pi p c f}{\kappa}} \equiv \frac{1-i}{\mu_{\mathrm{th}}}
$$

あり, $\rho, c, \kappa$ は試料の密度, 比熱, 熱伝導率を表わす. $\alpha$ と $\eta$ は光吸収係数と熱変換効率を意味し,

$\mathrm{T}(\vec{r}, t)$ と $\mathrm{I}(\vec{r}, t)$

は温度場と励起光強度を表わす。なお，(2)式で定義され るパラメーター $\mu_{\mathrm{th}}$ は「熱拡散長 (thermal diffusion length)」と 呼ばれ，発生した熱が，変調の一周期の間に周期的な波 動の様に試料中に拡散・浸透してゆく範囲を表してい る.

熱拡散長は光音響顕微鏡における重要なパラメーター で, 深さ方向に熱が拡散して行く範囲, 即ち深さ方向の 測定可能な範囲を示すとともに, 横方向の画像の熱拡散 による「ぼけ」，即ち空間分解能を意味している.

固体における光音響信号はRosencwaig とGershoにより， 試料長 1 , 光の吸収長 $\alpha^{-1}$, および熱拡散長 $\mu_{\mathrm{h}}$ の大小関係に よって解が6通りに分類されている。大まかに言えば，次 式のように

$$
V \propto \frac{\alpha(\lambda)}{f} \cdot I_{0} \propto \frac{N \cdot \sigma(\lambda)}{f} \cdot I_{0}
$$

光音響信号 $V$ は試料の吸収係数 $\alpha(\lambda)$ (従って試料濃度 $N$ と吸収断面積 $\sigma(\lambda)$ の積) および入射光強度 $I_{0}$ に比例し, 变
調周波数 12を参照されたい).

\section{2 圧電素子法}

固体に圧電素子を直接貼り付ける圧電素子法17)の特性 は, JacksonとAmerによる理論により, 熱拡散方程式と圧 電方程式(応力－歪を表わす式と誘電率を与える式が圧 電・電歪係数により結合した式)とを連立させて解く事に より求められている。理論解析の結果は前項とほぼ同じ で，(3)式が成り立つと考えてよい.

圧電素子法の利点としては, 変調周波数を高周波化で きるため，(2)式より熱拡散長を短く出来るため, 高い空 間分解能を実現する事ができる点，試料を開放したまま での測定が可能である点が挙げられる，但し，圧電素子 を用いた場合に注意しなければならない点として, 吸光 度 (光の吸収係数)に対する非直線性の問題が挙げられ る15)。(試料全体が光を吸収する場合には試料裏面に貼り 付けた圧電素子が伸びるために信号は正の極性である が，吸光度が大きい場合には試料表面でしか光が吸収さ れないため, 試料表面が熱膨張して試料裏面は逆に縮む ことになるため，信号の極性は負となる。)

\section{3 エッジ効果・熱源分布理論・Green関数法}

固体試料の端面付近で光音響信号が増加することは エッジ効果 (edge effect) と呼ばれ, 端面における熱波の反 射に起因する9). 理論的には端面に関してレーザー照射点 の鏡像の位置に仮想的なもう一つの熱源を配置して解析 を行えばよい10).

さらに表面欠陥の定量評価などに関しては, 熱源分布 理論 ${ }^{18)}$, Green関数法 ${ }^{18,19)}$ などがあるが, 詳しくは原論文 を参考されたい.

\section{4 深さ方向分析 (depth profiling)}

光音響法を映像化法として不可視物体内部の熱的な映 像化を行う場合には，(2)式より明らかなように励起光の 変調周波数 $f$ を変化する事により一周期の間に熱が拡散し 得る深さ $\mu_{\mathrm{th}}$ を変化させて, 熱拡散長の変化に対する画像 の違いから内部欠陥に関する情報を取得する事が可能と なる。この事は「デプスプロファイリング(depth profiling)」 と呼ばれ，光音響顕微鏡に限らず光熱変換効果を応用す る映像法に共通な基本原理となる。

\section{3. 光音響映像装置}

光音響映像化を行う装置は，1)試料を局所的に加熱す るためのレーザー光源および集光光学系, 2) 光ビーム走 査のための機械系，3) 音響センサにより圧力信号を電気 信号に変換する検出部，および4)ロックインアンプなど の信号処理系，5)光音響信号を制御・表示するためのコ ンピューターからなる.

光音響信号の検出手法にはコンデンサーマイクロフォ ンを用いるガス=マイクロフォン法, ならびに試料裏面に 圧電素子を貼り付ける圧電素子法があり, 光ビーム走査 
にはi）クローズドループで制御したガルバノ反射鏡方

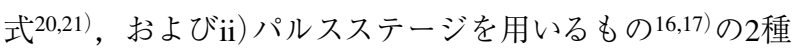
類の方式がある.

ガルバノ反射鏡を用いたものは高速，かつランダムに 走査できるために，試料が退色性を持つような生体や検 体などの測定に適する。一方，パルスモーターステージ を用いる駆動方式は工業製品などの精密計測に適するも のの, ステージの移動に時間がかかる点, 走行時の音響 的雑音の発生などの問題点を有していた.

Fig. 2に著者らが開発した光音響顕微鏡のブロック図を 示す22). 試料の走査に2軸リニアモーターステージを用い ているのが特徵であり，音響的な騒音が約 $30 \mathrm{~dB}$ 低下する ので，ガスマイクロフォン法を用いた精密計測に応用す る場合に特に有効である。なお, 光音響信号が变調周波 数に反比例する事を利用してBoxcar積分器を用いた検出を 用いる方式も提案されている23). 実際の実験をする場合 には参考になろう。

光音響顕微鏡装置は多くの場合光学顕微鏡を改良して 実現できるが，顕微鏡のリボルバー部に超音波レンズを 装着して, 高周波発振回路, 検出回路などの超音波顕微 鏡装置を一つに組み达めば,「光音響/超音波デュアルモー ド顕微鏡」を実現する事もできる24,25).

\section{4. 光音響顕微鏡の応用}

\section{1 半導体デバイスなどの非破壊検査}

光音響顕微鏡 ・ 映像法による構造物の非破壊検査に関 しては，1980年代からセラミックス製のタービンブレー ドの非破壊検査など様々な研究が行われている。半導体 デバイス内部の微小クラックの検出などに関する総合報 告がZhangらにより行われている26). pMOSトランジス ターを圧電素子型の光音響顕微鏡で評価した例をFig. 3に 示す.

彼らは固体試料裏面に圧電素子が接着されている単純 化されたモデルで, 表面近傍にあって深さzの位置に熱源 がある場合の理論式

$$
V(z)=V_{0} \cdot \exp \left(-\frac{z}{\mu_{\text {th }}}\right) \cdot \cos \left(\phi_{0}+\frac{z}{\mu_{\text {th }}}\right)
$$

を導いた。

(4)式における位相 $\phi_{0}$ をッッィングする事により, 深 さzにおける光音響信号を強調する事ができる. この光学

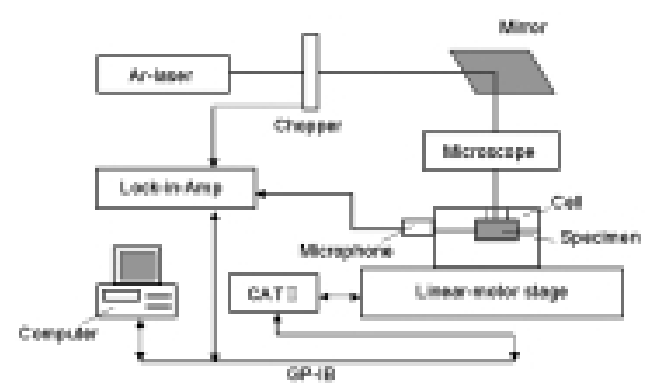

Fig. 2 The basic setup of the photoacoustic microscope with linear-motor driven stages.

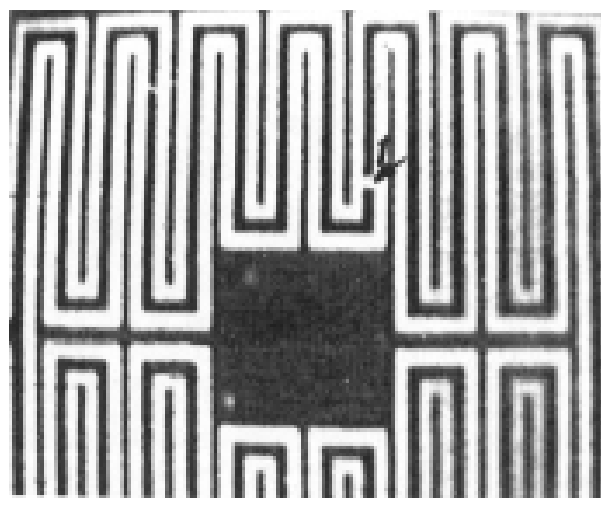

(a)

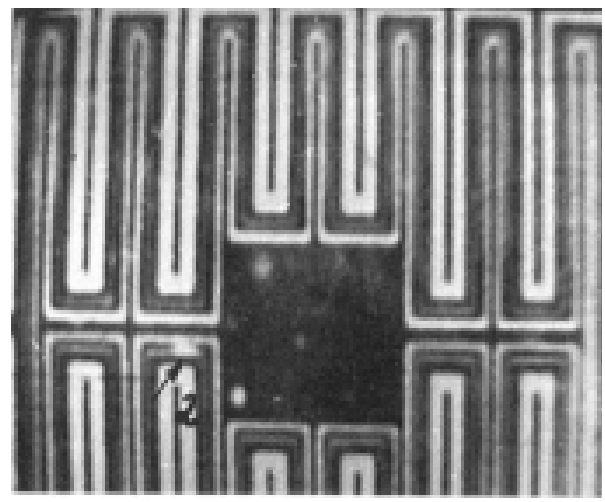

(b)

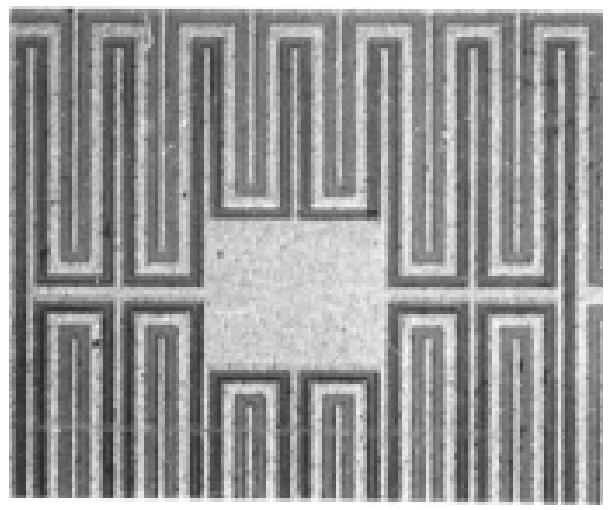

(c)

Fig. 3 Photoacoustic images of a pMOS transistor (a) the defect 1 (upper left), (b) defect 2 (upper right), (c) optical image(lower left). ${ }^{26)}$

顕微鏡における位相差顕微鏡と似ている手法により，コ ントラストを変化させて光音響像を得, それによって浅 い部位にある欠陥1 (Fig. 3a) と深い部位に存在する欠陷2 (同Fig.b) とを分離して検出できている. (c) は光学顕微鏡 像である. なお測定周波数は $283 \mathrm{kHz}$ である. 他にも半導 体材料の内部評価などの多くの分野で光音響顕微鏡が使 われているが, 詳細は他の紹介記事を参照されたい.

\section{2 ドライケミカル，並びにペーパークロマトグラ フィーの評価への応用}

血液検査，尿検査用紙などのいわゆる「ドライケミカ ル」は血液や尿などの体液に試薬を反応させ，その時に生 じる呈色反応などを利用して試験紙上で検査を行う手法 である。一般に，検査は目視で表の色と比較して行うた 
め，自動化が行い難いものであったが，ガルバノスキャ ン方式を用いた高速走査型の光音響映像法によりブドウ 糖による尿検査の呈色反応の検量線を求めた例がある.

尿検査用試験紙として一般に用いられているエームス 三共製のウロヘマ・コンビスティックス-Lを用い，試料の 退色が顕著であるので，光音響セルは簡易に脱着できる 構造のものを作成し, 走査の1点における信号取得に要す る時間も出来るだけ短縮した。測定条件はレーザーパ ワーが17 mW で変調周波数は $90 \mathrm{~Hz}$ であった.

光音響信号電圧 $V(\mathrm{x}, \mathrm{y})$ が試料濃度 $N(\mathrm{x}, \mathrm{y})$ に比例する ことから，

$$
\iint V(x . y) d x d y \propto \iint N(x, y) d x d y
$$

呈色反応により生じた光音響信号を(5)式の様に試料表面 にわたって積分した全光音響信号 (体積に相当する量)の試 料濃度のブドウ糖水溶液濃度依存性を求める事で, ドラ イケミカルにおいても液体分析手法における検量線に相 当するものを得る事ができた．検量線をFig. 4に示す8). 到 達感度は目視による検査よりも1桁高感度であった ${ }^{8,27)}$.

この手法は上記の例やペーパークロマトグラフ等の上 で生じる色素の分離過程の定量評価 ${ }^{21)}$, また次節のスギ 花粉の例などにも応用する事ができる.

\section{3 光音響顕微鏡のスギ花粉計測への応用}

アレルギー反応で良く知られているスギ (Cryptomeria japonica：CJ)花粉量の計測は空中花粉調査法により調べ られて花粉予報サービスとして提供されており, 新しい 計測法も開発中である.ここでは光音響顕微鏡を用いて スギ花粉粒塊を映像化し，その信号を画像全体にわたっ て積分することにより，(5)式をもとに全花粉量を求める 研究を紹介する28).

測定時の励起光ビームのビーム径は約 $30 \mu \mathrm{m}, \mathrm{Ar} レ$ ザーのパワーは約 $10 \mathrm{~mW}$ あるる.変調周波数は $90 \mathrm{~Hz}$ に設 定した，花粉重量を変化させながら，光音響信号を走査 平面上にわたって面積分したものをスギ花粉量に対して プロットする事により検量線を得る事が出来る。この場

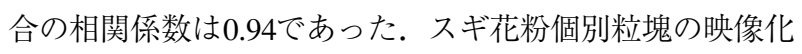
をも行った結果をFig. 5 に示す。走査範囲は 1 mm四方であ る.

光学像とほほ同品質のスギ花粉粒子(大きさは約 $30 \mu \mathrm{m}$ ) 1個までの映像化が達成されている。この場合に得られた

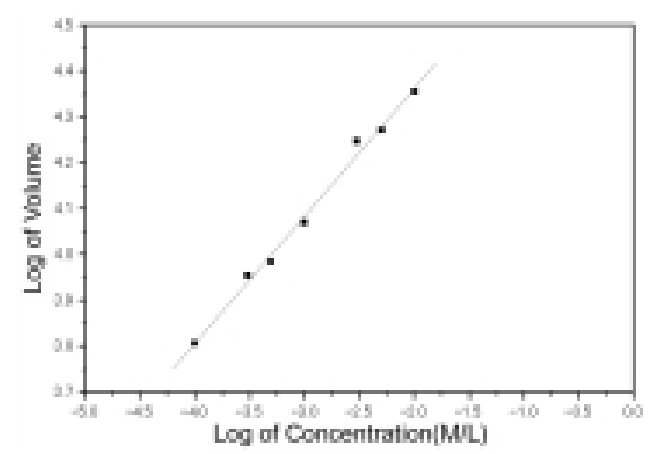

Fig. 4 Calibration curve for the Urohema Combistix-L.
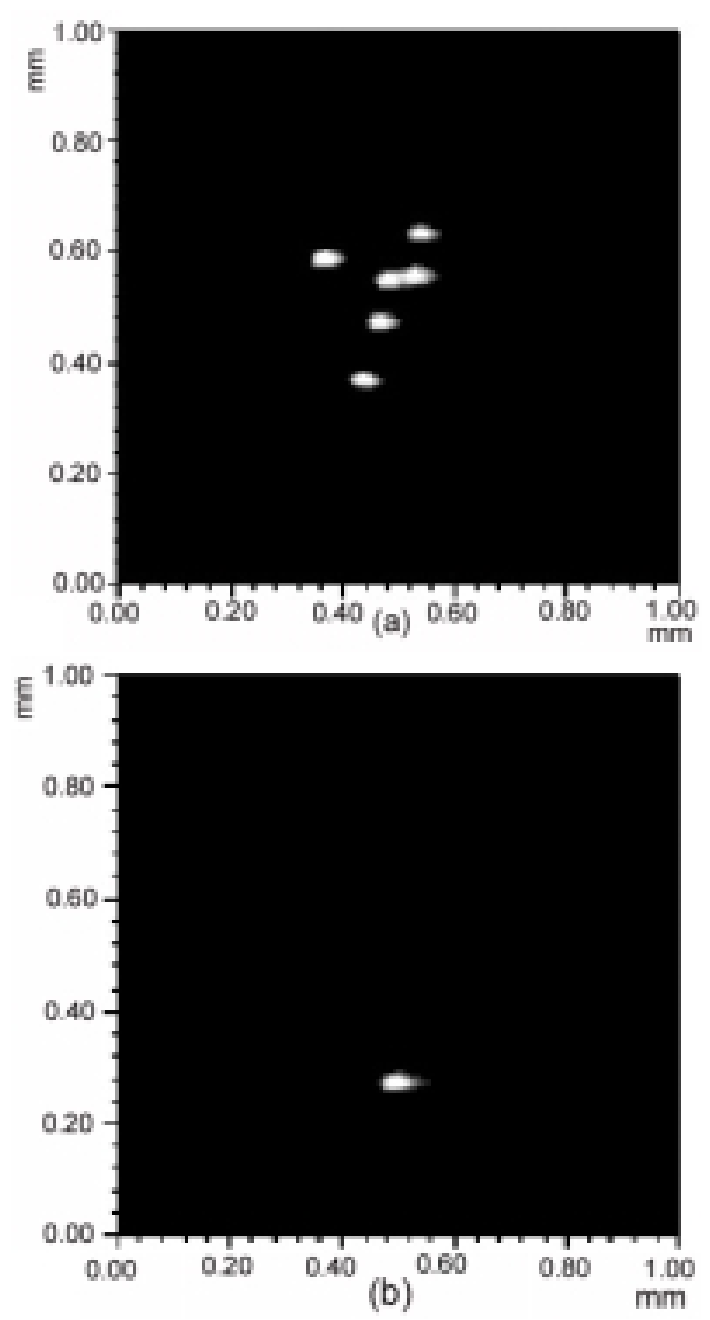

Fig. 5 Photoacoustic amplitude image of the Cryptomeria japonica (CJ) pollen, (a) 6 particles. (left), (b) single particle (right).

花粉粒子数と光音響信号との検量線をFig. 6に示す. 相関 係数を求めた結果， 0.97 となった。この值は光音響信号と 花粉重量の相関係数 0.94 よりも良く，直線性がより良いこ とが示された。この事から，将来的に光音響顕微鏡によ るスギ花粉自動計測が可能であると考えられる.

5. 光音響映像法, とくに光音響トモグラフィーの 生物・医学への応用

X線CTに代表されるトモグラフィー (tomography: 断層映 像法)に類似の光音響卜モグラフィー (photoacoustic tomography: PAT) の研究は1990年代の終わり頃からスタートし た.この場合にはX線CTの原理とは若干異なっており, レーザー・ビームで一様に試料を照射し, 光音響効果に より発生した音場を(例えば水中では)圧電素子などで検出 $L, 3$ 次元CTの再構成公式 (reconstruction formula)

$$
\alpha(\vec{r})=-\left.\frac{\beta}{2 c^{4} \pi C_{\mathrm{p}}} \iint_{S_{0}} d S_{0} \frac{1}{t} \cdot \frac{\partial p\left(\overrightarrow{r_{0}}, t\right)}{\partial t}\right|_{t=\left|\overrightarrow{r_{0}}-\vec{r}\right| / c}
$$




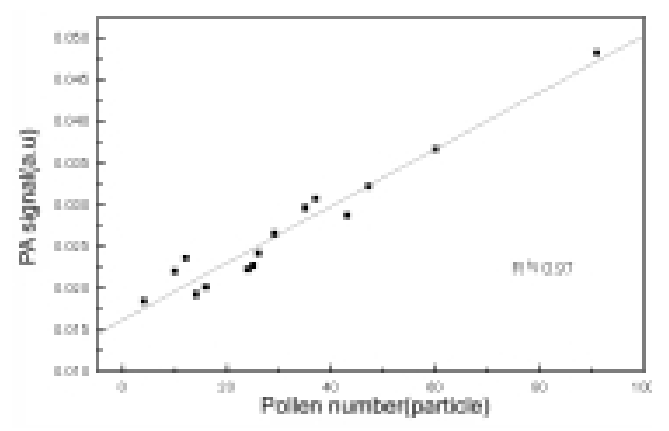

Fig. 6 The calibration curve of a photoacoustic amplitude as a function of the number of CJ pollen.

(ここで表面 $S_{0}$ は圧電素子で測定対象を走査する円筒表面 を表わし， $\beta$ は体積熱膨張係数， $c$ は水中での音速， $C_{\mathrm{p}}$ は 定圧比熱を表わす。)この原理に立脚したPATによりマウ スの脳の断層像を得た例が報告されている29). PATについ ては本特集の他の解説記事をも参照されたい.

\section{6. 結 論}

「不可視試料の可視化」という人間の夢を実現するため に分解能の向上や，さまざまな物理的原理を駆使した多 くの種類の顕微鏡がこれまでに生まれてきた。本稿では 光音響顕微鏡ならびに映像法の生物・医学的な応用を中 心に解説をしてきた.

しかし浅学菲才の著者には荷が重かった事も確かであ る。それを補う意味でこれまでの光音響法や光音響顕微 鏡に関する解説を参考文献としてあげておいたので，こ れからこの分野に関心をもたれる読者の方々は是非そち らも参考にしていただければ幸いである。（特に光音響顕 微鏡の開発の歴史的な面に関しては紙面の都合で十分ふ れる事が出来なかったので，文献1），2），9，１1)等を参 考にしていただきたい。）

\section{謝 辞}

本論文をまとめるにあたって，実験を担当していたた いた東北学院大学工学研究科応用物理学専攻博士課程大 学院生 (当時)の宮本 克彦氏(現東北大学電気通信研究所 COE研究員) に深く感謝いたします。筆者の研究の大半の 部分が同氏との共同研究であった事を申し添えたいと存 じます。

さらに，実験の面で全面的に協力いただいた同機械工
学専攻遠藤 春男教授, 本学工学部物理情報工学科郷右近 勝夫助教授, 機械創成工学科樋渡 洋一郎助教授, ならび に大学院生，学部学生諸君にも感謝の意を表します。

\section{参考文献}

1) 澤田 嗣郎編：光音響分光法一PAS一とその応用(学会出版七 ンター, 1982)

2) 澤田 嗣郎編：光熱変換分光法とその応用(学会出版セン 夕ー, 1997).

3) Y. H. Pao Ed.: Optoacoustic Spectroscopy and Detection, (Academic, New York, 1977).

4) A. Rosenczaig: "Photoacoustics and Photoacoustic Spectroscopy" (Wiley Interscience, New York, 1980).

5) A. Mandelis, Ed.: "Photoacoustic and Thermal Wave Phenomena in Semiconductors" (North Holland, New York, 1987).

6) A. Mandelis, Ed : "Principles and Perspectives of Photothermal and Photoacoustic Phenomena-Progress in Photothermal and Photoacoustic Science and Technology", Vol. I, (Elsevier, New York, 1992).

7) A. Mandelis, Ed.: "Non-Destructive Evaluation (NDE) - Progress in Photothermal and Photoacoustic Science and Technology", Vol. II, (Prentice Hall, Englewood Cliffs, 1994).

8) T. Hoshimiya: "Recent Research Development in Applied Chemistry", vol. 1, pp. 141 (Transworld Research Network, Kerala, 2002)

9）萩行 正憲，中島 信一：非破壊検査 36(1987) 730 .

10) 小島 誠治：電子通信学会超音波研究会資料US86-11 (1986).

11）星宮務：超音波テクノ5(1993) 50.

12) L. D. Favro, P. K. Kuo, and R. L. Thomas: 文献6)所収

13) Y. Sugitani, A. Uejima, and K. Kato: J. Photoacoust. 1 (1982) 217.

14) A. Rosencwaig and A. Gersho: J. Appl. Phys. 47 (1976) 64.

15) W. Jackson and N. M. Amer: J. Appl. Phys. 51 (1980) 3343.

16) R. L. Thomas, J. J. Pouch, Y. H. Wong, L. D. Favro, P. K. Kuo, and A. Rosencwaig: J. Appl. Phys. 51 (1989) 1152.

17) A. Rosencwaig and G. Busse: Appl. Phys. Lett. 36 (1980) 1.

18) T. Hoshimiya, H. Endoh, and Y. Hiwatashi: Jpn. J. Appl. Phys., vol.34, (1996) 2916.

19) T. Hoshimiya: "Acoustical Imaging”, vol.24, H. Lee Ed., (Kluwer Academic Press/Plenum Press, New York, 2000) 223.

20) R. S. Quimby: Appl. Phys. Lett. 45 (1984) 1037.

21) T. Hoshimiya: "Photoacoustic and Photothermal Phenomena II", Murphy J, Ed., (Springer Verlag, Heiderberg, 1990) 533.

22) T. Hoshimiya and K. Miyamoto: Ultrasonics 42, (2004) 993.

23) 田村景明, 岡山敏教, 加藤恭子, 得永 嘉昭: 日本音響学会 誌, 59 (2003) 250.

24) K. Miyamoto, M. Suzuki, T. Sannomiya, T. Hoshimiya, and N. Chubachi: Jpn. J. Appl. Phys. (2004).

25）星宮務：超音波テクノ(2004，刊行予定

26) Sh. Zhang and L. Chen: 文献5) 所収

27) T. Hoshimiya: Jpn. J. Appl. Phys. 31 (1992) 3474.

28) K. Miyamoto and T. Hoshimiya: Jpn. J. Appl. Phys. 42 (2003) 3084.

29) X. Wang, Y. Pang, G. Ku, G. Stoica, and L. V. Wang: Opt. Lett. 28 (2003) 1739 . 